\title{
Hanging Clothes on Wire and Its Association with Malaria Incidence in Batubara, North Sumatera
}

\author{
Budi Junarman Sinaga, Rahayu Lubis, Erna Mutiara \\ Masters Program in Public Health, Universitas Sumatera Utara
}

\begin{abstract}
Background: The majority of the mosquito and parasite life-history traits that combine to determine malaria transmission intensity are environmental depen-dent. Earlier evidence suggests that certain malaria vectors can spend large parts of their adult life resting indoors. This study aimed to examine the practice of hanging clothes on wire and its association with malaria incidence in Batubara, North Sumatera.

Subjects and Method: This was a case control study conducted in Batubara, North Sumatera in March 2018. A total of 176 people aged $\geq 15$ years consisting of 88 cases of malaria and 88 controls were selected for this study. The dependent variable was malaria incidence. The independent variable was hanging clothes on wire. The data were collected by questionnaire and analyzed by a logistic regression.

Results: Hanging clothes on wire was associated with an increased risk of malaria $(\mathrm{OR}=3.33$; $95 \% \mathrm{CI}=1.65$ to $6.73 ; \mathrm{p}=0.001$ ).

Conclusion: Hanging clothes on wire increases the risk of malaria.
\end{abstract}

Keywords: malaria, hanging clothes, wire.

Correspondence:

Budi Junarman Sinaga. Masters Program in Public Health, Universitas Sumatera Utara. Jl. Prof. T. Maas, Medan, North Sumatera. Email: budijunarman@yahoo.com. Mobile: o81361424297.

\section{BACKGROUND}

Malaria is one of the infectious diseases which is still a public health problem both in the world and in Indonesia. The World Malaria Report 2011 reports that 655 thousand people died of malaria, $6 \%$ of them occurred in Asia. Whereas, in 2015, World Malaria Report stated that there were 214 million malaria positive cases of which $88 \%$ were from Africa with 438,000 deaths (WHO, 2015). Malaria can cause death, especially in high-risk groups, namely infants, toddlers, and pregnant women. In addition, malaria directly causes anemia and can reduce work productivity (Indonesian Ministry of Health, 2016).

In 2016, in Indonesia, there were $65 \%$ of endemic districts in which around $45 \%$ of the population in the district were at risk of contracting malaria. Based on the results of the community survey during 2010 - 2013, malaria prevalence in Indonesia declined from $1.39 \%$ (Riskesdas, 2010) to $0.6 \%$ (Riskesdas, 2013). Meanwhile, based on reports received during 2000-2009, malaria morbidity rates tended to decrease by 3.62 per 1,00o population in 2000 to 1.85 per 1,000 population in 2009 and 1.96 in 2010. Meanwhile, the mortality rate due to malaria reaches $1.3 \%$.

In North Sumatra Province based on 2014 malaria case data from 33 regencies / cities in North Sumatra Province including 15 districts/cities that have received malaria elimination certificates and in 2015, there were 18 districts / cities still in the eradication phase, spread in 189 endemic villages high and moderate endemic. Endemic villages are certainly at risk of contracting malaria. In North Sumatra, malaria 
morbidity rates are still volatile. The malaria morbidity rate in 2014 is (API) 1 per 1000 population, this has decreased compared to the 2015 data (API) of 0.51 per 1000 population. The number of clinical cases in 2014 was reported to be 83,618 cases while in 2015 there were 91,236 cases. On the other hand, the high microscopic power error rate still ranges from $20-60 \%$ as reported from the district / city (North Sumatra Provincial Health Office, 2016).

Batu Bara Regency has 15 health centers. Of the 15 health centers in Batu Bara District, 5 of them are malariaendemic health centers, the number of clinical malaria sufferers in Batu Bara in 2015 was 5,593 clinical cases while the number of malaria positive was 1205 cases and clinical malaria in 2016 were 4,856 cases and the number malaria positive was 580 cases. From the data above, it can be seen that there is a decrease in malaria cases both clinically and positively. In 2016, there were no recorded deaths due to malaria (Batu Bara District Health Office, 2017).

Bad environmental factors are one of the risk factors in malaria incidence. This environmental problem has been emphasized in the president's instructions regarding malaria elimination. The elimination phase carried out by the government in 2008 referred to the Three Presidential Instruction on World Malaria Day, which emphasized the importance of efforts to increase awareness and awareness of Malaria through: 1 . The increase of education, education, socialization and advocacy to the wider community; 2. The increase of knowledge and skills of officers in the treatment and treatment of Malaria; 3. Environmental maintenance in order not to become a nest of mosquitoes (Ministry of Health of Republic of Indonesia, 2015).

\begin{abstract}
SUBJECTS AND METHOD
1. Study Design

This was an analytic observational study with a case control design. The study was conducted in Batu Bara District, in Medan, May 2018.
\end{abstract}

\section{Study Sample}

Samples totaling 136 people were selected by purposive sampling, consisting of 68 subjects aged $\geq 15$ years who were malaria positive and 68 negative malaria subjects.

\section{Study Variables}

The dependent variable is the incidence of endemic malaria. The independent variable is the habit of hanging clothes and using wire. The data were collected using questionnaires and observation sheets.

\section{Data Analysis}

The data were analyzed using a multiple logistic regression.

\section{Univariate Analysis}

Table 1 shows the frequency distribution of the habit of hanging clothes and the use of wire mesh on malaria incidence. Table 1 shows that the subjects who had the habit of hanging clothes had more malaria (42.6\%) than those who did not hang clothes (11.8\%).

The subjects who did not wire netting (30.9\%) were more likely to suffer from malaria than those who installed gauze wire (16.2\%).

\section{Bivariate Analysis}

Table 2 showed the result of bivariate analysis of the relationship between the habit of hanging clothes and the use of wire netting with endemic malaria. Table 2 showed that there was a relationship between the habit of hanging clothes and the incidence of endemic malaria in Batu Bara District. The habit of hanging clothes increase the risk of malaria by $3.13(\mathrm{OR}=$ 3.13 ; $95 \% \mathrm{CI}=1.41$ to 6.93 ; $\mathrm{p}=0.003$ ). 
There was a relationship between wireand the incidence ofendemic malaria in Batu Bara District. Not using the wire

Table1.The habitual frequency distribution of hanging clothes and the use of wire mesh on the incidence of malaria

\begin{tabular}{lcccc}
\hline \multirow{2}{*}{ IndependentVariable } & \multicolumn{2}{c}{ Malaria (+) } & \multicolumn{2}{c}{ Malaria (-) } \\
\cline { 2 - 5 } & N & \% & n & \% \\
\hline The Habit of Hanging Clothes & & & & \\
Yes & 29 & 42.6 & 25 & 36.8 \\
No & 8 & 11.8 & 6 & 8.8 \\
The use of wire mesh & & & & \\
No & 21 & 30.9 & 28 & 41.2 \\
Yes & 11 & 16.2 & 8 & 11.8 \\
\hline
\end{tabular}

Table 2.The results of bivariate analysis about the relationship between the habit of hanging clothes and the use of wire with the incidence of endemic malaria

\begin{tabular}{|c|c|c|c|c|c|c|c|}
\hline \multirow{3}{*}{ Variables } & \multicolumn{4}{|c|}{ Control } & \multirow{3}{*}{ OR } & \multirow{3}{*}{$95 \% \mathrm{CI}$} & \multirow{3}{*}{$\mathbf{p}$} \\
\hline & \multicolumn{2}{|c|}{ Malaria (+) } & \multicolumn{2}{|c|}{ Malaria (-) } & & & \\
\hline & $\mathbf{n}$ & $\%$ & $\mathbf{n}$ & $\%$ & & & \\
\hline \multicolumn{8}{|c|}{ The Habit of } \\
\hline \multicolumn{8}{|c|}{ Hanging Clothes } \\
\hline Yes & 29 & 42.6 & 25 & 36.8 & & & \\
\hline No & 8 & 11.8 & 6 & 8.8 & 3.13 & 1.41 to 6.93 & 0.003 \\
\hline \multicolumn{8}{|l|}{ The Use of Wire } \\
\hline No & 21 & 30.9 & 28 & 41.2 & 255 & 127 to 511 & 0006 \\
\hline Yes & 11 & 16.2 & 8 & 11.8 & 2.55 & 1.27 to 5.11 & 0.006 \\
\hline
\end{tabular}

3. Multivariate Analysis

Table 3 showed the results of multiple logistic regression analysis. Table 3 showed that the habit of hanging clothes $(\mathrm{OR}=4.14$;

Table 3.The Result of Multiple Logistic Regression Analysis

\begin{tabular}{lcccc}
\multicolumn{1}{c}{ Variables } & \multirow{2}{*}{ OR } & \multicolumn{2}{c}{ 95\% CI } & p \\
\cline { 3 - 4 } & & Lower limit & Upper limit & \\
\hline The habit of hanging clothes & 4.14 & 1.81 & 9.49 & 0.001 \\
Not using the wire & 2.99 & 1.38 & 6.49 & 0.006 \\
Constants & & & & $<0.001$ \\
\hline
\end{tabular}

95\% $\mathrm{CI}=1.81$ to $9.49 ; \mathrm{p}=0.001)$ and not using the wire $(\mathrm{OR}=2.99 ; 95 \% \mathrm{CI}=1.38$ to $6.49 ; \mathrm{p}=0.006)$ increase the risk of malaria.

\section{DISCUSSIONS \\ 1. The Effect of Hanging Clothes Habit on the Incidence of Endemic Malaria in Batu Bara}

The results of the study showed that there was an effect of the habit of hanging clothes with the incidence of endemic malaria in Batu Bara District. The result of this study was supported by the study done by
Lerebulan et al. (2013) which stated that there was a relationship between the habit of hanging clothes and the incidence of malaria in the working area of the Wertamrian District Health Center, West Southeast Maluku Regency. The results of the study showed that $60.6 \%$ of the research subjects had the habit of hanging clothes. 
There were still many people who have lack of awareness toward the importance of creating and maintaining environmental sanitation. Bad habits that can lead to malaria include hanging clothes on the bed, hangers behind the door, in the window, in the chair, in the kitchen, and in the bathroom. Dirty clothes that were hung anywhere and scattered inside the house would eventually become a nesting place for mosquitoes (Lerebulan et al., 2013).

The low awareness and participation of the community about the importance of maintaining environmental hygiene and sanitation can be caused by the low level of knowledge of the community in an effort to prevent the development of malaria mosquitoes. Conyers (1994) explained that community participation was a form of voluntary community participation based on determinants and awareness of the community itself which was active in increasing the community participation. Participation itself was an embodiment of changes in attitude and behavior.

Arsyad (2015) also mentioned that there was a relationship between the habit of hanging clothes and malaria in Tongoa Village, Palolo District, Sigi Regency. Individuals who did not have the habit of hanging clothes were 0.04 time less likely to experience malaria.

The habit of hanging clothes was a risk factor for malaria. The big amount of hanging clothes can be used as a hiding place for mosquitoes. This would increase the potential for contact between mosquitoes and humans. People who have the habit of hanging clothes in a room were 3.1 times more likely to have malaria compared to those who did not have the habit of hanging clothes (Nurbayani, 2013).

\section{The Effect of the Use of Wire on the Incidence of Endemic Malaria in Batu Bara}

The results showed that there was a relationship between the use of wire mesh and the incidence of endemic malaria in Batu Bara. The result of this study was supported by a study done by Ainunnahqi (2012) which stated that there was a relationship between the use of wire mesh and the incidence of malaria in Tambak District, Banyumas Regency. Individuals who did not use wire mesh increase the risk of malaria by 25 times $(\mathrm{OR}=25.08$; $\mathrm{p}=$ 0.001). A study done by Nababan and Umniyati (2018) which was conducted in Central Javashowed that all research subjects in the endemic malaria areas did not use wire on the house ventilation.

Darmiahet al. (2017) explained that there was a relationship between the behavior and the incidence of malaria in Katingan District, Kalimantan. Poor hygiene behavior increased the risk of developing malaria by 9,299 times (OR $=9.29 ; 95 \%$ $\mathrm{CI}=2.29$ to 37.64). Protection of vulnerable people can be done by avoiding mosquito bites, providing medicines to prevent malaria and vaccination. The installation of wire on doors, windows and ventilations in the house can prevent the mosquitoes.

The results of this study also showed that $72.7 \%$ of respondents in the case group did not use wire netting whereas wire netting was very helpful in preventing mosquitoes at night where the Anopheles mosquitoes were active at night. According to Harya (2015), it was stated that the use of ventilation wire that was not full could invite the mosquitoes into the house through ventilation, therefore, it increase the contact between mosquitoes and humans. This was in line with a study done by Lestari (2007) which stated that the incidence of malaria was caused by the 
house which did not use the wire net so that it facilitated the mosquitoes to enter the house.

\section{REFERENCES}

Ainunnahqi R (2012). Identifikasi Faktor Risiko yang Berhubungan dengan Kasus Malaria di Kecamatan Tambak Kabupaten Banyumas Tahun 2012.

Arsyad G (2015). Faktor-Faktor yang Berhubungan dengan Kejadian Malaria di Desa Tongoa Kecamatan Palolo Kabupaten Sigi. JIK, 1(19): 935 1014.

Conyers D (1994). Perencanaan Sosial di Dunia Ketiga: Suatu Pengantar. Yogyakarta: Gadjah Mada University Press.

Darmiah YS, Baserani, Khair A, Isnawati, Suryatinah Y (2017). Hubungan Tingkat Pengetahuan Dan Pola Perilaku dengan Kejadian Malaria di Kabupaten Katingan Provinsi Kalimantan Tengah. Journal of Health Epidemiology and Communicable Diseases, 3(2): 36-41.

Harya SA (2015). Pengaruh Faktor Lingkungan dan Perilaku terhadap Kejadian Malaria di Kecamatan Siabu Kabupaten Mandailing Natal Tahun 2015. Tesis Fakultas Kesehatan Masyarakat USU.

Kemenkes RI (2015). Pedoman Manajemen Malaria Tahun 2015. Direktorat Jenderal PPM-PL. Jakarta.
(2016). Profil Kesehatan Indonesia Tahun 2017. Jakarta. Dinas Kesehatan Kabupaten Batu Bara. 2017. Laporan Kasus Malaria Tahun 20102017.

Lerebulan N, Bawotong J, Rottie J (2013). Hubungan Kebiasaan Masyarakat Desa Tumbur dengan Kejadian Malaria di Wilayah Kerja Puskesmas Kecamatan Wertamrian Kabupaten Maluku Tenggara Barat. Ejournal keperawatan (e-Kp), 1(1): 1-9.

Lestari EW, Sukowati S, Soekidjo, Wigati (2007). Vektor Malaria di Daerah Bukit Menoreh, Purworejo, Jawa Tengah. Media Penelitian dan Pengembangan Kesehatan, 17(1): 30-35.

Nababan R, Umniyati SR (2018). Faktor lingkungan dan Malaria yang Memengaruhi Kasus Malaria di Daerah EndemisTertinggi di Jawa Tengah: Analisis Sistem Informasi Geografis. Berita Kedokteran Masyarakat, 34(1): 11-18. https://doi.org/10.22146/bkm.26941

Nurbayani L (2013). Faktor Risiko Kejadian Malaria di Wilayah Kerja Puskesmas Mayong I Kabupaten Jepara. Jurnal Kesehatan Masyarakat, 2(1).

WHO (2015). Roll Back Malaria Partnership: Defeating malaria in Asia, the Pacific, Americas, Middle East and Europe. World Health Organization on behalf of the Roll Back Malaria Partnership Secretariat, Geneva. 